\title{
Making sense of Teachers' (dis)belief in the educational value of social media: A case of two language teachers in Rwanda
}

DOI:

10.1504/IJTEL.2020.107983

\section{Document Version}

Accepted author manuscript

Link to publication record in Manchester Research Explorer

Citation for published version (APA):

Kwihangana, F. (2020). Making sense of Teachers' (dis)belief in the educational value of social media: A case of two language teachers in Rwanda. International Journal of Technology Enhanced Learning.

https://doi.org/10.1504/IJTEL.2020.107983

\section{Published in:}

International Journal of Technology Enhanced Learning

\section{Citing this paper}

Please note that where the full-text provided on Manchester Research Explorer is the Author Accepted Manuscript or Proof version this may differ from the final Published version. If citing, it is advised that you check and use the publisher's definitive version.

\section{General rights}

Copyright and moral rights for the publications made accessible in the Research Explorer are retained by the authors and/or other copyright owners and it is a condition of accessing publications that users recognise and abide by the legal requirements associated with these rights.

\section{Takedown policy}

If you believe that this document breaches copyright please refer to the University of Manchester's Takedown Procedures [http://man.ac.uk/04Y6Bo] or contact uml.scholarlycommunications@manchester.ac.uk providing relevant details, so we can investigate your claim.

\section{OPEN ACCESS}


Making sense of Teachers' (dis)belief in the educational value of social media: A case of two language teachers in Rwanda

\author{
Felix Kwihangana
}

Manchester Institute of Education

University of Manchester

Oxford Road

Manchester, M13 9PL

Email: felix.kwihangana@manchester.ac.uk

\begin{abstract}
This study reports on the beliefs of two cases of EFL teachers regarding the integration of social media in the teaching of English in Rwanda. Using semi-structured interviews, the study found that the teachers believed social media had the potential to improve their students' learning of English but could also change their teacher positions within the institution. While both teachers viewed social media positively, their social media practices were more informed by the potential impact of the technology on their status as teachers than its potential pedagogical contribution to students' learning of English. These findings highlight the importance of understanding teacher's self-positioning before, during and after technology integration processes to ensure that the proposed technology integration aligns with their image of the self in specific contexts.
\end{abstract}

Keywords: teacher beliefs, social media, educational technology, EFL, ICT in language teaching

\title{
1. Introduction
}

Researchers have highlighted the role of teacher beliefs on technology integration (Ertmer et al., 1999; Kim et al., 2013). These technologies include social media which have become useful tools for language learners to develop different skills in foreign language learning contexts (Blattner \& Lomicka, 2012). Teacher beliefs help to explain practice (Borg, 2006) and account for variation in technology practices among teachers working under similar contextual factors (Ertmer, 2005). For example, although the two teachers in the current study had both received an internal memo urging them and their students to adopt social media in their teaching and learning, their ultimate social media practice largely depended on their beliefs about the educational value of these media. 
Social media's ubiquity has made these web-based technologies very attractive for many people across the world. They occupy a crucial role in the Rwandan government's ICT in education strategy as it vows to use new information and communication technologies to achieve quality education which is often blamed for students' poor skills in English and other subjects (Ministry of Education, 2016). The rapid development and push for social media in education through policies and memos in this country calls for a clear understanding of how teachers' attitudes and beliefs about these technologies influence their practice. Yet, despite studies that have explored the relationship between beliefs and technology use, few studies seek to understand social media integration through the specific lens of teacher beliefs even though these technologies are among the most popular technologies for the current generation of learners. In developing countries, research is even almost inexistent, hence affecting our ability to understand social media beliefs and practices of teachers in these contexts. This study sought to contribute to efforts aimed at bridging that knowledge gap. It explores social media beliefs of English as a Foreign Language (EFL) teachers working in the Rwandan context. The findings highlight the role of teachers' self-positioning in enacting their social media beliefs and puts teachers working in under-resourced and under-researched contexts in the spotlight.

\section{Social media in education}

Social media are 'Internet-based technologies' that allow users to communicate and collaborate with each other, create/co-create, share, manage information; and/or form online communities in which they learn and build relationships (Mustonen, 2009; Hansen, Schneiderman and Smith, 2011; Mao, 2014). These technologies allow 'ordinary users' to dominate the internet (Selwyn, 2011, p. 1) by friending, conversing, collaborating and creating platforms that reflect projects of shared interests which have potential to 'generate a buzz' (Ang, 2011, p. 34). They constitute 'an inexpensive, easy to-use, interactive, dynamic, collaborative, unregulated, almost ubiquitous and democratic platform' (Agarwal, 2011, p. 40) that gives foreign language learners unparalleled opportunities for practice and an exposure to vast amounts of 'cultural knowledge' inaccessible to them in the traditional classroom (Miller, Morgan and Koronkiewicz, 2018).

More importantly, social media integration in education responds to the needs and learning styles of the new generation of college/university students keen to remain in control of their learning by navigating and negotiating information independently online (Selwyn, 2011; Camacho, 2012). 'Social media can be utilised to deliver teaching material, educational information, updates and facilitate communication and collaboration.' (Chugh and Ruhi, 2018, p. 606).The educational use of social media therefore constitutes an 'innovative way in sharing and delivering knowledge' (Shahril et al., 2018, p. 382) that is appealing to learning institutions.

In fact, calls for educational institutions to integrate these technologies are motivated by much more than the understanding that social media can extend learning beyond traditional settings (Schwartz, 2009; Camacho, 2012; Bahati, 2015). Today's learners are spending more time on social media (Lantz-Andersson, Vigmo and Bowen, 2012). Thus, it is feared that students would lose interest in an educational system that does not value such technologies which are 'inherently collaborative' (Miller, Morgan and Koronkiewicz, 2018) and 'increasingly ubiquitous' in students' daily lives (Mao, 2014). Some educators are taking advantage of this ubiquity by conceptualising social media in their teaching as 'a true extension of the classroom community' to enable 
learners to continue discussing learnt topics beyond the classroom walls (Bahati, 2015; Pai et al., 2017, p. 109). Social media platforms empower users and their educational application is expected to foster the principles of collective and learner-centred learning models (Agarwal, 2011; Camacho, 2012; Shahril et al., 2018). It is because of these affordances that the educational use of social media grows at 'an astonishing pace'(Balubaid, 2013, p. 409).

\subsection{Social media in foreign language teaching}

Foreign language learning/teaching, especially the teaching of English as a Foreign Language (EFL) can benefit a lot from social media networks integration. According to Miller et al. (2018), 'it seems natural' for teachers to use social media in foreign language teaching because of the 'inherently collaborative nature' of these technologies. They give EFL learners opportunities to interact with distant native speakers in the target language (Borau et al., 2009). Thus, social media offer learners unprecedented 'real-world' opportunities to develop different linguistic skills and 'intercultural communicative competence' (Stevenson and Liu, 2010, p. 235; Kessler, 2018, p. 210; Miller, Morgan and Koronkiewicz, 2018) on platforms where English is used as a 'lingua mundi' (Lantz-Andersson, Vigmo and Bowen, 2012). For example, studies on language learning involving Facebook (Blattner and Lomicka, 2012) and Twitter (Borau et al., 2009) or a combination of Twitter and Facebook (Miller, Morgan and

Koronkiewicz, 2018) found that social media give learners more exposure to the target language and opportunities for practice.

Apart from studies of social media in EFL, many studies have demonstrated the value of social media in other foreign languages. A recent study on the views of Australian learners of Chinese as a foreign language using WeChat to interact with native speakers of Chinese (Jiang and $\mathrm{Li}, 2018$ ) showed that not only students enjoyed and appreciated this opportunity to interact with native speakers, they also became more confident in using the target language. The authors concluded that the addition of WeChat tasks in their teaching 'compensated for some of the limitations of classroom teaching, where students did not have opportunities to use the target language in reallife situations.' (Jiang and Li, 2018, p. 13) Relatedly, in their study of social media use in the learning of Spanish at an American university, Miller et al. (2018) found that Twitter and Facebook had enabled the creation of a 'semi-natural, online community, which mimics authentic language use and interaction'. Other studies that focused on the use of wikis in language learning (Lin and Yang, 2011) or speaking skills development through video blogging (Shih, 2010) have all indicated that these media contribute to the development of students' grammar, vocabulary, pronunciation and overall ability to communicate in the target language. However, due to the diversity and multiplicity of social media, it is not possible to identify which social media are more advantageous to foreign language learners (Miller, Morgan and Koronkiewicz, 2018).

\subsection{Critical issues in social media integration in education}

Since 'the original designs for most social media tools are intended for life or commercial purposes', their educational use is not straightforward and should result from an evaluation of its true educational worth rather than its popularity (Mao, 2014; Shahril et al., 2018). In practice, students' acceptance of social media as a language learning tool ( see Blattner \& Lomicka, 2012) often contrasts with their lack of a 'welldefined awareness of social media as a concept for formal, structured learning in school environments.' (Mao, 2014). In fact, learners expect teachers 'to use social technologies 
in ways that align with their established social practices'(Kessler, 2018)'. However, these practices are often in contrast with their teachers' expectations. A recent literature review on the educational use of Facebook identified the 'lack of academic language usage' as one of the challenges affecting social media use in education (Chugh and Ruhi, 2018, p. 611). For example, Selwyn's (2011) study of college students' uses of Facebook found that their Facebook-posts were 'ostensibly mundane, prosaic and often 'anti-intellectual' (p.170). This difference of perspective on social media usage is probably the root of 'student resistance to adapting social networks for educational use' (Pai et al., 2017, p. 125).

Nevertheless, today's EFL teachers cannot deny social media a place in their teaching even though their reluctance to the educational use of these technologies remains a recurrent issue (Pai et al., 2017, p. 125). Some scholars have even argued that the use of social technologies 'has become so ubiquitous' in language teaching that their 'absence in our classroom is quite noticeable' (Kessler, 2018). In fact, social media and language learning have now become almost inseparable, and this brings new challenges for language teachers. As Vie (2008, p. 19) argued, social media have become a 'battlefield' where teachers are on the 'losing side' because of the ability of these technologies to 'topple traditional classroom hierarchies of power in unpredictable ways'. Thus, since teachers are generally less technologically skilled than their students (Vie, 2008; Selwyn, 2011), their beliefs will play an important role in the way they approach social media that are favourited by students who lack 'critical technological literacy skills' despite their technological 'know-how' (Vie, 2008, p. 10). Given these differences, it is only by understanding teachers' social media beliefs that they can be supported in bridging their 'digital disconnect' with students (Selwyn, 2011; Camacho, 2012).

\subsection{The link between Teacher Beliefs and technology integration}

Like all other educational technologies, social media use is subject to factors that are known to influence technology integration such as teachers' perception of the affordances of the technology to their classes (Hughes, 2005; Wood et al., 2005) and their attitudes and beliefs about technology (Ertmer, 1999; Ertmer, Gopalakrishnan and Ross, 2001; Wood et al., 2005; Hew and Brush, 2007). Technology beliefs regulate the level of comfort teachers have with any technology presented to them. They make the same technology a 'blessing' for some and a 'curse' for others (Ertmer, 2005, p. 30). Indeed, research suggests that technology integration involves more than the technology itself because teachers use technology in a way that aligns with their beliefs (Fang, 1996; Ertmer et al., 2012).

Those beliefs influence teachers' 'actual instructional behaviour in the classroom' (Patrick and Pintrich, 2001, p. 118), and thus 'affect teaching and learning in one way or another' (Fang, 1996, p. 50). Although teachers' technology practices 'do not ultimately always reflect teachers' stated beliefs' (Borg, 2003, p. 91), with favourable beliefs, 'even teachers who are not pedagogically, technically, or socially strong can carry out classroom technology innovations' (Zhao et al., 2002, p. 508). For example, technology-using teachers have often cited internal factors (beliefs included) as their biggest enablers (Ertmer et al., 2012). Similarly, Zhao et al. (2002, p. 492) found that teachers who had difficulties integrating technologies that conflicted with their pedagogical beliefs could integrate them 'much more smoothly' when they matched their beliefs. 
While these studies provide a convincing case on the role of beliefs in teachers' technology practices, they are mostly based in contexts where teachers are well trained and have access to resources, unlike those working in developing countries where training and resources remain inaccessible. Thus, we need to explore how technology beliefs developed in such under-resourced contexts affect teachers' educational uses of technologies, particularly social media. It is in response to this need that the current study brings to light social media beliefs of two teachers working in Rwanda. The key research questions were; (1) What beliefs do the two Rwandan EFL teachers hold regarding social media use for educational purposes? and (2) How do these beliefs reflect the realities of ICT usage in their working environment?

\section{Materials and Methods}

\subsection{Participants}

The two teachers in this study, Arthur and Joseph (pseudonyms), were selected based on their technological and professional experience in English language teaching at their institution. They had been teaching English for seven and six years respectively. Arthur had a degree in linguistics and literature in English and had undertaken several certificate courses, including one specifically on e-learning offered by a large American university. Joseph had recently obtained a master's degree in Teaching English as a Foreign Language which complemented his bachelor's degree in English with education. Like Arthur, he had taken various professional online courses on technology integration. Joseph was introduced to web-based technologies as a student by some of his teachers and considered himself a skilled user of popular social media. He credited online courses for honing his social media skills; especially the web-skills course for language teachers which he said had taught him how to use social media to teach English. Both teachers had used the course management system NICENET as a result of their technology training but had later suspended it for unconvincing outcomes.

\subsection{Study design}

This study followed a qualitative design which is 'person-centred'(Richards, 2003, p. 9) and thus widely used in studies of teacher beliefs (Pajares, 1992; Borg, 2003). A case study design was adopted for this study because such a design 'centres on one or a few individuals'(Brown, 1988, p. 2) for in-depth analysis of the case without seeking any forms of generalizability. Participants took part in a 45 to 50 minute in-depth interview about their social media beliefs that was 'neither strictly structured with standard questions, nor entirely non-directive' (Kvale, 2008, p. 12). The interviews were semistructured and followed a guide developed based on the existing literature and validated by an expert in educational technology and teacher education. All interviews were conducted via Skype, hence allowing me to overcome geographical barriers by interviewing participants who were located in a remote area (Deakin and Wakefield, 2014). Participants were experienced users of Skype and gave their consent to the automatic recording of their interview using a third-party software. After the interviews, I conducted a 'denaturalized transcription' of the recordings that consisted of removing 'idiosyncratic elements of speech' such as stutters and pauses from the interview (Oliver, Serovich and Mason, 2005, pp. 1273-1274). The transcripts were then shared with the participants for checking and comments. 


\subsection{Data analysis}

The data were analysed following a thematic approach (Braun and Clarke, 2006) that started during the transcription phase by highlighting 'meaningful and manageable chunks of text' relevant to the aims of the research (Attride-Stirling, 2001, p. 391). After transcription, the data were repeatedly read, looking for meanings and patterns (Braun and Clarke, 2006) with codes being added next to the highlighted text. In accordance with Braun \& Clarke's (2006, p. 86) view, the analysis was characterised by 'back and forth' movements in which codes were generated 'on the basis of salient issues that arise in the text itself' (Attride-Stirling, 2001, p. 390). These codes were constantly revisited, re-organized, amended or dropped for lack of support as new understanding of the data emerged. Although the coding was 'data-driven', constant reference to the literature was made to ensure that each theme 'captures something important in relation to the overall research question' (Braun and Clarke, 2006, p. 82).

Both participants were constituted as different cases whose data were first analysed independently before a cross-case comparison of themes was conducted to identify similarities and discrepancies between the two cases. Findings in this study are reported in a way that highlights those similarities and differences between the beliefs and practices of the two teachers. This paper reports on two of the three case studies that formed an original research which was conducted as a part of a postgraduate degree at a UK higher learning institution. These two cases were selected for reporting in this paper because of the contrasts that emerged between them regarding their social media beliefs and practices.

\section{Results}

\subsection{Social media beliefs and in-context technology practices}

The understanding of social media for both cases focused on the utilitarian value of these technologies, which often resulted from the participants' personal experiences. Arthur defined them as 'Internet-based social interactions where people share or create ideas, information, and many things they've got.' Similarly, Joseph defined social media as 'Those tools that make people meet and share some news, make comments with each other, share photos. That is the social media thing.' Arthur and Joseph's actual social media usage reflected their definitions. It involved sharing news, interacting with 'friends' and planning social events.

However, both teachers approached social media differently when it came to integrate them in their teaching of English. Arthur for example interacted with his students on Facebook but insisted that these interactions were non-educational: 'just interacting with them like friends.' Nevertheless, he acknowledged the educational value of these interactions:

I might take that opportunity if there is...maybe someone has typed a kind of mistake..., I wouldn't maybe rebuke the person, but I can, in a tricky way, correct the mistake...And I think the student would benefit from that. (Arthur, my emphasis)

He justified this hidden educational agenda of his social media usage by the desire to keep students motivated to chat with him without any language anxieties. Relatedly, Arthur gave his students tasks that required them to access what he called online 'tons 
and tons of materials to read' which give students extended exposure to the English language and improve their technological skills. He regretted that his teachers did not 'encourage us by giving us assignments via Internet. For instance, setting exercises online, giving us links to read from for further details of what they would have taught.' His aim to create technology-mediated linguistic experiences for his students through social media had strong similarities with the technology usage he wished he had had as a student. Thus, in addition to social media like Facebook where the writing is more prominent, he also created opportunities for his students through various forms of media 'like podcasts for listening, videos from YouTube, links and so on' in his teaching. Nevertheless, his idea of social media extends to other forms of technology that he found relevant to his teaching of English.

While Arthur was trying to integrate some social media in his English language teaching strategies, Joseph's social media use did not include any educational application even though he considered himself to be a skilled social media user and repeatedly characterised social media as 'fun'. He believed learning activities on social media must be fun, not 'boring' for students. This belief originated from his selfdirected learning experience with some social media: 'I tried to listen to YouTube videos where I have native speakers that gave me the accent of native speakers and it made my problem of hearing and communicating with native speakers go away.'

Although he strongly viewed social media as 'a platform, a place where to practice English outside the classroom,' Joseph did not attempt to turn any social media into such a fun platform for his students. He was also self-critical about this lack of action: 'I wish I could have done that because I know it [using social media for teaching] is a good thing... Unfortunately, I never tempted to use it.' He blamed his overdue social media integration on his students' lack of knowledge of social media as an educational tool and his inability to convince them otherwise.

So, changing this perspective, changing this idea they have in mind [about social media as a purely social tool] is one of the things that made me wonder "OK. How do I go about it?" That's what made me wait a little bit. 'Let me wait a little bit and maybe learn how I can go about it.'

Although Joseph noted that his students were skilled social media users and saw himself as a skilled social media user, he still believed that they needed training in using social media 'for studying, for self-study, for improving their language skills and made no attempt to help them to acquire this skill he deemed important.

Unlike Joseph who considered himself a skilled social media user, Arthur rejected this labelling. His perception of students' social media skills was informed by experience and was neither idealized nor generalized. For example, he recalled that some students showed a 'kind of resistance to these changes of teaching methodologies' while using NICENET (a content management platform) because 'some students were reluctant' to work independently and preferred to 'receive everything from the teacher.' Arthur indicated that his students' use of 'Facebook, Twitter, YouTube, Wikipedia, and blogs' for personal purposes meant that they were prepared and 'happy to use them' in their learning. However, he observed that their social media skills 'might be limited', especially regarding plagiarism: 
They go to Internet, they surf the world, but it's not done adequately. Because you might give them an exercise and they just go and copy things and paste them, you know, then they bring you all: "We've done this!"

Arthur's concerns about his students' lack of information referencing skills did not affect his appreciation of their readiness for educational social media usage. In fact, Arthur extended his criticism to teachers: 'we still need some trainings about...some uses of social media. I think I don't have enough knowledge about using all that in teaching.' For Arthur, students' skills will increase if teachers themselves are skilled social media users. However, he believed teachers were too busy to focus on the development of their social media skills and those of their students: with the 'current timetable, it might not be possible because it seems there is no time for that,' he explained.

\subsection{Beliefs about achieving learning objectives through social media}

Arthur argued that the primary need of his students was 'English that will help them to communicate.' He expected social media to play an important role in helping them achieve this objective because of the opportunities for interactions outside the classroom that the technologies provided. He believed social media would help 'solve a lot of problems we are used to come across in class' regarding the use of English. He also believed that social media integration could improve students' participation in communication activities and avert the limitations caused by his large classes. Arthur also saw social media usage as an opportunity for him to adopt a learner centredpedagogy and abandon what he called a 'traditional way of teaching where students have to sit in class and consume what the teacher is giving.' In his vision of a social media pedagogy, he anticipated that all students would be more engaged 'because students would go and work on their own, on their own pace and they would be participating...everyone would participate.' These expectations are indicative of the teacher's intention and confidence to achieve learning objectives using social media.

Joseph on the other hand, found that the curriculum his institution offered did not 'quite meet the purpose of the students' learning' because it emphasized grammar teaching. In his understanding, the use of social media in the existing curriculum was untenable. He wanted to make the English language curriculum more communicative and saw that technology could help bring the changes he wanted:

Like YouTube, Facebook in writing, YouTube in speaking or listening, they get to know how grammatical rules are used, they get to know them in writing or speaking and it activates that knowledge and they can use that in real situations, not just having it in their heads and not being able to use it.

However, he did not act towards taking advantage of these social media affordances because he believed his technology integration initiatives could not be institutionally supported. He blamed this on a 'rigid' syllabus: 'So if I introduce something else, something new it would require me very long time for them [college and department leaders) to understand it.' He wanted to integrate social media in his teaching if it would allow him to enact changes within the curriculum. Otherwise, he feared being blamed in case his students failed exams after a unilateral integration of social media in his teaching. This was because students in parallel streams had to sit for the same test prepared at the departmental level. For Joseph, the fear of potential risks resulting from 
social media integration exceeded their anticipated benefits; and this warranted his decision not to act towards the integration.

On the other hand, Arthur wanted to give a learner-centred twist to his educational social media use which he described as 'very low' and 'not the way I would like to use them' because of its teacher-centredness. He believed his teacher-centred social media use could 'compromise the purpose of social media itself' and thus wanted to infuse his practice with the flexibility of social media. He understood the ubiquity of learning with social media, noting that his 'students wouldn't be seated in class necessarily, they might go and do that online where everybody might be anywhere.' While planning for social media integration, Arthur found social media crucial in fostering informal cooperative learning (Johnson and Johnson, 1999), especially through writing activities:

With the writing again, I think this would help much...with these social media, I think they can post their activity, what they have done on a given topic and then I try to read what they have done or ask them for peer correction. They have comments on each other's activities.

Arthur's willingness to fully integrate social media in his teaching and make them a key aspect of his teaching strategy was not much an institutional issue as a personal one. $\mathrm{He}$ did not worry about students' resistance or the possibility of students failing because of their involvement in teacher-sanctioned social media activities. Unlike Joseph who blamed the rigidity of the syllabus at the institution, Arthur believed that his students' limited access to digital devices and the Internet were the major challenges. As he recalled, 'students have had problems saying they don't have machines.' Thus, his only barrier to achieving course objectives while integrating social media activities in his teaching was the availability of resources.

\subsection{The nature of teacher-Student relationship on social media}

The teachers' own experience of student-teacher interactions (when they were themselves students) influenced their perception of an ideal teacher-student relationship on social media. Arthur was conscious that his past relationship with his teachers who were not technologically supportive influenced his social media relationship with students. 'We are of what we might have experienced', he observed. He then explained

...when I was a student, it was not easy for me to interact with my teachers, especially when it is not in class. So, I wouldn't find it [interacting with students on Facebook] ... quite normal but with the frequent uses of these technological tools, I think the idea is changing. That's why I have even accepted to become a 'friend' of some of them. (Arthur)

Arthur wanted this social media usage to be unhinged by his lack of proper technology experience as a student: 'it shouldn't affect me anymore. It should stop. That is what I'm fighting for.' He recalled that his interaction with teachers was limited, an experience he claimed to spare his students by 'friending' and interacting with them on social media.

While Arthur believed he had the responsibility to initiate his students on using social media for language learning, Joseph believed this had to come naturally because he did not want to force social media onto his students. Drawing from his lacklustre 
experience with the online course management system NICENET at the institution, Joseph feared that actively inviting students to use social media in their learning of English would not lead to any better results.

So, because they went there [on NICENET) and posted a comment because it was an obligation, they don't even know what they did. They don't selfevaluate. They don't use these metacognitive strategies to evaluate their learning, which is a problem.

Joseph's disappointment with NICENET not only eroded his confidence in his students' readiness for educational social media, it also pushed further any potential attempts to use social media for teaching purposes. Joseph's social media pushback contrasted with his conviction that he knew how to engage students with social media for learning: 'You don't bring it as an expert who is telling them, 'use it as this'.' 'So, you direct them to what you want them to talk about, but in a way like the 'cool' teacher, not like an authoritative teacher.' In fact, he contradicted this same view by suggesting that a successful integration of social media in teaching required 'total control of the class, especially in the beginning.' These self-contradicting views only support Joseph's earlier view that he lacked conclusive knowledge of 'how to go about' social media integration. His concerns about losing students' trust in case his introduction of social media failed also belie his lack of confidence in his social media skills even though he claimed otherwise. He believed that 'students trust us as teachers' and that a failed social media introduction would be a betrayal of that trust.

A distinctive feature between the two cases is their understanding of whether social media usage potentially enhanced or undermined their teacher position. Arthur felt obliged to adopt social media because using them is now inevitable for his survival in this technological era. He was 'afraid of being left behind by the society in large, and by modern teaching methodologies in particular.' He viewed social media as the only choice he had: 'I think I need to be involved too [in using social media]. Otherwise I would be left in traditions.' Consequently, he nurtured a 'personal commitment' to social media for survival purposes. Joseph, on the other hand, saw these social media as a potential threat to his status as a 'cool teacher' if their integration failed. This difference in perspectives determined their urge to adopt social media in their teaching.

\section{Discussion}

In accordance with previous research that underscored EFL teacher's positive views of social media in language teaching (Başöz, 2016); both teachers viewed social media as tools that could potentially contribute to the achievement of their teaching and learning objectives. They both highlighted the relevance of social media in developing different language skills (speaking, listening, reading, writing and grammar). Despite the teachers' positive beliefs regarding the affordances of social media to their course objectives, their social media integration had remained at best minimal.

A key factor in the teachers' social media usage was their perceived impact on their teacher status and students' reaction to the introduction of social media as a learning tool. While Arthur saw social media usage as a requirement to remain relevant in the digital age and worked towards this goal, Joseph viewed them as a potential threat to his teacher image in front of students in case social media usage was not successful. Hence, Arthur wanted to use social media to ascertain his position as a non-traditional teacher while Joseph delayed their use to avoid losing his acquired status of a 'cool' 
teacher. These conflicting views corroborate Ertmer's (2005) claims that beliefs make the same technology a blessing or a curse depending on individuals.

Relatedly, although both teachers also held views that social media offers learners 'real world' opportunities (Stevenson and Liu, 2010), their views differed on how to incorporate social media in their teaching. For Joseph, this meant an overhaul of the entire teaching curriculum, which he saw as unlikely for lack of institutional involvement. By considering the curriculum overhaul a prerequisite to social media integration, he put himself in a comfortable position that absolved him of any requirements to act towards social media integration in his teaching even though the institution expected him to do so. His questioning of the 'rigid' curriculum reflected earlier observations that one of the consequence of the development of web 2.0 tools knowledge construction and sharing is that 'teachers and learners question 'old' ideas and begin to reject them' (Motteram and Sharma, 2009, p. 86). Consequently, by not taking concrete initiatives to integrate social media, his ideas for a curriculum change initiated by social media integration remained a set of ideals that he believed could not be achieved.

Teachers' anticipation of students' expectations was also crucial in shaping and directing their social media intentions and beliefs. In the case of Arthur, students' willingness to use social media for educational purposes was recognized even though they still needed to learn to avoid plagiarism. On the other hand, Joseph believed students were only ready to use social media for personal purposes and would hardly accept the educational use of these technologies. Because of their different views on students' social media readiness, Arthur was giving his students activities that involved social media use while Joseph avoided engaging them through social media activities. This indicates that teachers' preconceptions of students' technological readiness have a strong impact on what technological innovations can be brought into the language classroom.

In accordance with research that underscored the influence of experience on teacher beliefs (Pajares, 1992), both teachers used their personal experiences with technology to inform their plans for students' technology experiences on their EFL course. For example, Arthur's lack of positive technology experience as a student galvanized him to spare his students a similar dissatisfaction. Contrariwise, Joseph's successful self-directed learning with social media led him to believe that students' social media usage would come naturally without his intervention.

According to Hughes (2005, p. 297), 'the power to develop innovative technology-supported pedagogy lies in the teacher's interpretation of the technology's value for instruction in the classroom.' Joseph's inaction in directing his students to use social media in their English language learning activities exemplifies an underlying understanding that social media would not benefit his students' learning within the existing curriculum. His lack of enthusiasm for social media came from his fear that a failed social media integration would put into question his comfortable status as a trusted teacher. On the contrary, Arthur's attempts to use social media can be explained by his understanding that social media usage would benefit his students and make him a better version of himself, a non-traditional teacher. Eventually, Arthur felt that there was a lot to gain through social media integration while Joseph found that there was a lot to lose for the same initiative.

This study has also revealed the importance of teachers' underlying self-doubt on their perceived ability to successfully use social media for learning. As Nishino (2012) pointed out, teachers' beliefs are influenced by their perceived efficacy. Both teachers' beliefs about social media integration were often moderated by their feeling of 
a general lack of social media skills (Arthur) or specific skills for educational social media usage (Joseph). Even though Arthur and Joseph had taken courses on e-learning and web-skills for language teaching which included aspects of social media, they believed that social media integration required them to possess more skills than they already had to succeed. This disinclination to use social media despite prior training prove the argument that 'there has long been a reluctance to use technology for language teaching even when teachers have received preparation.' (Kessler, 2018)

Therefore, the lack of training in social media was not enough to explain the reluctance to use social media for the two teachers. As some scholars have argued, 'the teacher must believe that he or she is capable of implementing technology successfully in order to act on those beliefs.' (Mueller et al., 2008, p. 1526) For example, although Joseph relayed the idea that students do not understand the educational application of social media as a formal learning environment (Mao, 2014), his admission that he did not know 'how to go about it' indicate that personal reasons influenced how he perceived his students' social media readiness. Thus, despite claiming that students are familiar with social media and willing to integrate them in their learning, a view that conforms to Blattner \& Lomicka's (2012) finding, Joseph found getting students to adopt social media as a formal learning environment puzzling and decided to avoid using them altogether.

\section{Conclusion}

This study has highlighted the beliefs of both teachers that social media was valuable in developing their students' linguistic skills even though these beliefs did not translate into practice. The findings have also underscored that the positive social media beliefs of the two teachers were not only a result of their experience and expectations from social media but also depended on the teachers' anticipated reaction of students towards educational social media usage in their environment. Although the study only reports findings from two teachers, its findings add to the growing body of knowledge on how second/foreign language teachers in low income countries like Rwanda adopt technologies for teaching and learning purposes. The study's contribution is the exemplification of the connection between teachers' perception of the impact social media integration in under-resourced classrooms may have on their status as teachers and the likelihood of actual plans for social media integration regardless of their technology skills and beliefs.

The study has shown that a perceived positive impact of the educational use of social media on a teacher's status and position in their institution leads to more efforts to integrate these technologies into their teaching activities. This contribution is based on only two EFL teachers at an institution where social media usage is compulsory for teachers and students, though the policy is not strictly reinforced. A larger sample which includes both educators and their students may generate more insights on the social media beliefs prevailing in this and similar EFL contexts. Further studies could also explore how this works in less compelling but equally under-resourced contexts. Finally, research shows that privacy remains a major issue in the use of social media in education (Chugh and Ruhi, 2018). Since, this study was conducted prior to the major social media privacy issues that were made public recently, researchers may explore whether the positive attitudes and beliefs in the educational value of social media remain unchanged in the wake of these revelations about privacy breaches by major social media companies. 
Acknowledgments

I would like to thank Dr Diane Slaouti for her support and feedback on earlier versions of the work reported here. 


\section{References}

Agarwal, N. (2011) 'Collective Learning: An Integrated Use of Social Media in Learning Environment', in White, B., King, I., and Tsang, P. (eds) Social Media Tools and Platforms in Learning Environments. Berlin, Heidelberg: Springer, pp. 37-51. doi: 10.1007/978-3-642-20392-3_3.

Ang, L. (2011) 'Community relationship management and social media', Journal of Database Marketing \& Customer Strategy Management. Palgrave Macmillan UK, 18(1), pp. 31-38. doi: 10.1057/dbm.2011.3.

Attride-Stirling, J. (2001) 'Thematic networks: an analytic tool for qualitative research', Qualitative Research, 1(3), pp. 385-405. doi: 10.1177/146879410100100307.

Bahati, B. (2015) 'Extending Student' Discussions Beyond Lecture Room Walls via Facebook', Journal of Education and Practice, 6(15), pp. 160-171.

Balubaid, M. A. (2013) 'Using Web 2.0 Technology to Enhance Knowledge Sharing in an Academic Department', Procedia - Social and Behavioral Sciences, 102, pp. 406420. doi: 10.1016/j.sbspro.2013.10.756.

Başöz, T. (2016) 'Pre-service EFL Teachers' Attitudes towards Language Learning through Social Media', Procedia -Social and Behavioral Sciences, 232, pp. 430-438. doi: 10.1016/j.sbspro.2016.10.059.

Blattner, G. and Lomicka, L. (2012) 'Facebook-ing and the Social Generation: A New Era of Language Learning', Alsic: Apprentissage des Langues et Systèmes d'Information et de Communication. Adalsic, 15(1). doi: 10.4000/alsic.2413.

Borau, K. et al. (2009) 'Microblogging for Language Learning: Using Twitter to Train Communicative and Cultural Competence', in Spaniol, M. et al. (eds) Advances in Web Based Learning-ICWL 2009 . Berlin: Springer, pp. 78-87. doi: 10.1007/978-3-64203426-8_10.

Borg, S. (2003) 'Teacher cognition in language teaching: A review of research on what language teachers think, know, believe, and do', Language teaching, 36(2), pp. 81-109. doi: 10.1017/S0261444803001903.

Borg, S. (2006) Teacher cognition and language education: Research and Practice. London: Continuum.

Braun, V. and Clarke, V. (2006) 'Using thematic analysis in psychology', Qualitative Research in Psychology, 3(2), pp. 77-101. doi: 10.1191/1478088706qp063oa.

Brown, J. D. (1988) Understanding research in second language learning : a teacher's guide to statistics and research design. Cambridge: Cambridge University Press.

Camacho, S. (2012) 'Empowering Student Experience through Social Media', in Ying, L. F., Hashim, M. N., and Chiat, L. F. (eds) Essays on Issues in the Music and Its function. UM Book Series on Research in Musicology 4 . Kuala Lumpur: LAP Lambert Academic Publishing, pp. 60-75. Available at:

https://umexpert.um.edu.my/file/publication/00003917_90090.pdf\#page=91 (Accessed: 13 June 2018).

Chugh, R. and Ruhi, U. (2018) 'Social media in higher education: A literature review of Facebook', Education and Information Technologies, 23(2), pp. 605-616. doi: 10.1007/s10639-017-9621-2. 
Deakin, H. and Wakefield, K. (2014) 'Skype interviewing: reflections of two PhD researchers', Qualitative Research, 14(5), pp. 603-616. doi:

10.1177/1468794113488126.

Ertmer, P. A. (1999) 'Addressing first- and second-order barriers to change: Strategies for technology integration', Educational Technology Research and Development. Kluwer Academic Publishers, 47(4), pp. 47-61. doi: 10.1007/BF02299597.

Ertmer, P. A. et al. (1999) 'Examining Teachers' Beliefs About the Role of Technology in the Elementary Classroom', Journal of Research on Computing in Education, 32(1), pp. 54-72. doi:

10.1080/08886504.1999.10782269doi.org/10.1080/08886504.1999.10782269.

Ertmer, P. A. (2005) 'Teacher pedagogical beliefs: The final frontier in our quest for technology integration?', Educational Technology Research and Development. Kluwer Academic Publishers, 53(4), pp. 25-39. doi: 10.1007/BF02504683.

Ertmer, P. A. et al. (2012) 'Teacher beliefs and technology integration practices: A critical relationship', Computers \& Education. Pergamon, 59(2), pp. 423-435. doi: 10.1016/J.COMPEDU.2012.02.001.

Ertmer, P. A., Gopalakrishnan, S. and Ross, E. (2001) 'Technology-Using Teachers: Comparing Perceptions of Exemplary Technology Use to Best Practice.', Journal of Research on Technology in Education, 33(5).

Fang, Z. (1996) 'A review of research on teacher beliefs and practices', Educational Research, 38(1), pp. 47-65. doi: 10.1080/0013188960380104.

Hansen, D. L., Schneiderman, B. and Smith, M. A. (2011) Analyzing social media networks with NodeXL: insights from a connected world. Burlington, USA: Morgan Kaufmann.

Hew, K. F. and Brush, T. (2007) 'Integrating technology into K-12 teaching and learning: current knowledge gaps and recommendations for future research', Educational Technology Research and Development. Kluwer Academic PublishersPlenum Publishers, 55(3), pp. 223-252. doi: 10.1007/s11423-006-9022-5.

Hughes, J. (2005) 'The Role of Teacher Knowledge and Learning Experiences in Forming Technology-Integrated Pedagogy', Journal of Technology and Teacher Education, 13(2), pp. 277-302. Available at:

https://search.proquest.com/docview/200085080/fulltextPDF/E185D5D706F041F4PQ/ 1 ? accountid=12253 (Accessed: 13 June 2018).

Jiang, W. and Li, W. (2018) 'Linking up learners of Chinese with native speakers through WeChat in an Australian tertiary CFL curriculum', Asian-Pacific Journal of Second and Foreign Language Education, 3(1), pp. 1-16. doi: 10.1186/s40862-0180056-0.

Johnson, D. W. and Johnson, R. T. (1999) 'Making Cooperative Learning Work', Theory Into Practice, 38(2), pp. 67-73. doi: 10.1080/00405849909543834.

Kessler, G. (2018) 'Technology and the future of language teaching', Foreign Language Annals. Wiley/Blackwell (10.1111), 51(1), pp. 205-218. doi: 10.1111/flan.12318.

Kim, C. et al. (2013) 'Teacher beliefs and technology integration', Teaching and Teacher Education. Pergamon, 29, pp. 76-85. doi: 10.1016/J.TATE.2012.08.005. 
Kvale, S. (2008) Doing interviews. London : Sage Publications Ltd.

Lantz-Andersson, A., Vigmo, S. and Bowen, R. (2012) 'Students' framing of language learning practices in social networking sites', in Bradly, L. and Touesny, S. (eds) CALLl: Using, Learning, Knowing. 2012 EUROCALL Conference Proceedings. Dublin: Research-publishing.net, pp. 161-166.

Lin, W.-C. and Yang, S. C. (2011) 'Exploring students' perceptions of integrating Wiki technology and peer feedback into English writing courses', English Teaching: Practice and Critique July, 10(2), pp. 88-103. Available at:

http://education.waikato.ac.nz/research/files/etpc/files/2011v10n2dial1.pdf (Accessed: 14 June 2018).

Mao, J. (2014) 'Social media for learning: A mixed methods study on high school students' technology affordances and perspectives', Computers in Human Behavior. Pergamon, 33, pp. 213-223. doi: 10.1016/j.chb.2014.01.002.

Miller, A. M., Morgan, W. J. and Koronkiewicz, B. (2018) 'Like or Tweet: Analysis of the Use of Facebook and Twitter in the Language Classroom', TechTrends. doi: 10.1007/s11528-018-0341-2.

Ministry of Education (2016) 'ICT in Education Policy'. Kigali, Rwanda: Ministry of Education. Available at:

http://mineduc.gov.rw/fileadmin/user_upload/pdf_files/ICT_in_Education_Policy_appr oved.pdf (Accessed: 3 January 2018).

Motteram, G. and Sharma, P. (2009) 'Blending Learning in a Web 2.0 World', International Journal of Emerging Technologies \& Society, 7(2), pp. 83-96. Available at: http://www.swin.edu.au/ijets (Accessed: 19 June 2018).

Mueller, J. et al. (2008) 'Identifying discriminating variables between teachers who fully integrate computers and teachers with limited integration', Computers \& Education. Pergamon, 51(4), pp. 1523-1537. doi: 10.1016/J.COMPEDU.2008.02.003.

Mustonen, P. (2009) Social media - a new way to success. Turku. Available at: http://www.utupub.fi/bitstream/handle/10024/113610/Kre1_2009.pdf?sequence=1 (Accessed: 14 June 2018).

Nishino, T. (2012) 'Modeling Teacher Beliefs and Practices in Context: A Multimethods Approach', The Modern Language Journal. Wiley/Blackwell (10.1111), 96(3), pp. 380-399. doi: 10.1111/j.1540-4781.2012.01364.x.

Oliver, D. G., Serovich, J. M. and Mason, T. L. (2005) 'Constraints and Opportunities with Interview Transcription: Towards Reflection in Qualitative Research', Social Forces. Oxford University Press, 84(2), pp. 1273-1289. doi: 10.1353/sof.2006.0023.

Pai, A. et al. (2017) 'Using Facebook Groups to Encourage Science Discussions in a Large-Enrollment Biology Class', Journal of Educational Technology Systems, 46(1), pp. 103-136. doi: 10.1177/0047239516675898.

Pajares, M. F. (1992) 'Teachers' Beliefs and Educational Research: Cleaning Up a Messy Construct', Review of Educational Research. Buchmann Clark Feiman-Nemser \& Floden Fenstermacher Munby Nespor Tabachnick Wilson, 62(3), pp. 307-332. doi: $10.3102 / 00346543062003307$.

Patrick, H. and Pintrich, P. R. (2001) 'Conceptual change in teachers' intuitive conceptions of learning, motivation, and instruction: The role of motivational and 
epistemological beliefs', in Torff, B. and Sternberg, R. J. (eds) Understanding and teaching the intuitive mind. Student and teacher learning. Mahwah, NJ: Lawrence Erlbaum, pp. 117-143.

Richards, K. (2003) Qualitative inquiry in TESOL. Basingstoke: Palgrave Macmillan.

Schwartz, H. L. (2009) 'Facebook: The New Classroom Commons? - ProQuest', The Chronicle of Higher Education, 56(7). Available at:

https://search.proquest.com/docview/214653519?accountid=12253 (Accessed: 14 June 2018).

Selwyn, N. (2011) 'Social media in higher education', in Gladman, A. (ed.) The Europa World of Learning 2012. London: Routledge. Available at:

http://sites.jmu.edu/flippEDout/files/2013/04/sample-essay-selwyn.pdf (Accessed: 14 June 2018).

Shahril, A. M. et al. (2018) 'Using Social Media as One of Learning Tool: Facebook Enhances Learning Practices among Higher Learning Students in Malaysia', International Review of Management and Business Research, 7(2), pp. 380-386. doi: 10.30543/7-2(2018)-7.

Shih, R.-C. (2010) 'Blended learning using video-based blogs: Public speaking for English as a second language students', Australasian Journal of Educational Technology, 26(6), pp. 883-897. doi: 10.14742/ajet.1048.

Stevenson, M. P. and Liu, M. (2010) 'Learning a Language with Web 2.0: Exploring the Use of Social Networking Features of Foreign Language Learning Websites', CALICO Journal, 27(2), pp. 233-259. Available at:

https://www.jstor.org/stable/pdf/calicojournal.27.2.233.pdf (Accessed: 14 June 2018).

Vie, S. (2008) 'Digital Divide 2.0: “Generation M" and Online Social Networking Sites in the Composition Classroom', Computers and Composition. JAI, 25(1), pp. 9-23. doi: 10.1016/J.COMPCOM.2007.09.004.

Wood, E. et al. (2005) 'Teachers' Perceptions: barriers and supports to using technology in the classroom', Education, Communication \& Information, 5(2), pp. 183206. doi: 10.1080/14636310500186214.

Zhao, Y. et al. (2002) 'Conditions for Classroom Technology Innovations', The Teachers College Record, 104(3), pp. 482-515. 